\title{
Avaliação da composição química e da toxicidade do óleo essencial de folhas e frutos da Jatropha gossypifolia $\mathrm{L}$.
}

\section{Assessment of chemical composition and toxicity of the essential oil of leaves and fruits of Jatropha gossypifolia $L$.}

\author{
Juciely Moreti dos Reis ${ }^{1}$; Willian Ferreira da Costa ${ }^{2}$; \\ Sandro Minguzzi ${ }^{3}$; Rogério César de Lara da Silva ${ }^{4 *}$
}

\section{Resumo}

\begin{abstract}
As folhas e frutos da Jatropha gossypifolia foram avaliados quanto a sua composição química. O óleo essencial das folhas obtido por hidrodestilação e o material graxo do albúmen das sementes e o óleo das sementes foram avaliados quanto a composição química e toxicidade frente a Artemia salina. $\mathrm{O}$ rendimento na extração dos óleos foi de $26,6 \%, 38,4 \%$ e $0,0365 \%$ para as sementes, albumen e folhas, respectivamente. As toxicidades dos óleos obtidos do albúmen e das sementes, frente a Artemia salina, foram de 74,25 $\pm 0,21 \mu \mathrm{g} \mathrm{mL}^{-1}$ e 78,66 $\pm 0,25 \mu \mathrm{g} \mathrm{mL}^{-1}$, respectivamente. $\mathrm{O}$ índice de saponificação e o índice de acidez do óleo do albúmen foram de $165,4 \mathrm{mg} \mathrm{KOH} \mathrm{g}^{-1}$ e de $10 \%$, respectivamente. Cromatografia gasosa com deteç̧ão por ionização em chama (CG-DIC) foi utilizada para análise do perfil de ácidos graxos do albúmen e sementes. Alto percentual para o ácido heptadecanoico (C17:0) foi determinado para o óleo das sementes com 35,81\%. Treze compostos foram identificados no óleo essencial obtido de folha por cromatografia gasosa acoplada a espectrometria de massas (CG-EM). Os índices de Kovats para os compostos foram calculados e comparados aos da literatura.

Palavras-chave: Óleos voláteis. Ácidos graxos. CG-EM. Euphorbiaceae. Jatropha gossypifolia L.
\end{abstract}

\begin{abstract}
The leaves and fruits of Jatropha gossypifolia L. were evaluated for their chemical composition. The essential oil of the leaves, were obtained by hydrodistillation and the fatty material of albumen and seeds were evaluated for chemical composition and toxicity in the Artemia salina assay. The extraction yield of oil was $26.6 \% 38.4 \%$ and $0.0365 \%$ for the seeds, leaves and albumen, respectively. The toxicity of the oil obtained from the albumen and seeds against in the Artemia salina were $74.25 \pm 0.21 \mu \mathrm{g} \mathrm{mL}-1$ and $78.66 \pm 0.25 \mu \mathrm{g} \mathrm{mL}^{-1}$. The saponification and acidity index for the oil albumen was $165.4 \mathrm{mg} \mathrm{KOH}$ $\mathrm{g}^{-1}$ and $10 \%$, respectively. Gas chromatography with flame ionization detection (GC-FID) was used to analyze the fatty acid profile of albumen and seeds. High percentage (35.81\%) for heptadecanoic acid (C17:0) was determined for the oil form of the seeds. Twelve compounds were identified in the essential oil obtained from the leaves by gas chromatography-mass spectrometry (GC-MS). The Kovats Index for compounds were calculated and compared to those of literature.
\end{abstract}

Key words: Volatile oils. Fatty acids. GC-MS. Euphorbiaceae. Jatropha gossypifolia L.

1 Graduada em Química Licenciatura, Universidade Estadual de Mato Grosso do Sul. E-mail: jucielymoreti@hotmail.com

2 Docente do Departamento de Química da Universidade Estadual de Maringá - DQI-UEM. E-mail: wfcosta@uem.br

3 Professor Adjunto da Universidade Estadual de Mato Grosso do Sul - Química Licenciatura - Unidade de Naviraí. E-mail: $\underline{\operatorname{sming}(\mathbf{u}, \mathrm{uems} . \mathrm{br}}$

4 Professor Adjunto da Universidade Estadual de Mato Grosso do Sul - Química Licenciatura - Unidade de Naviraí. E-mail: rcsilva@uems.br 


\section{Introduction}

In Brazil, many plants are used for domestic use as medicament. Several of these plants still unexplored and needs to be investigated through research for use as new drugs. In vegetation of the savannah it can be found the family Euphorbiaceae, represented by approximately 222 genera and 7.000 species. The genus Jatropha belongs to this family and consists of 175 tropical and subtropical species. The species Jatropha gossypifonlia L. is found in the savannah where it can be known as purple pinion or angry pinion (OLIVEIRA et al., 2008; SERVIN et al., 2006).

It is known for its medicinal properties and as a pesticide, containing mainly lignins and diterpenes. $J$. gossypifolia is also found in other countries like India, where studies show the discovery of new diterpenes, flavonoids and lignans (OLIVEIRA et al., 2008). From the ethyl acetate/hexane (EtOAc/He) leaves extract of $J$. gossypifolia L., Biswanath et al. (2003) has isolated cleomiscosin A and a coumarin-lignin. Studies of Ravindranath et al. (2003) on the leaf extract obtained with dichloromethane/methanol $(\mathrm{DCl} / \mathrm{MeOH})$ led to isolation of a new diterpenoid with antibacterial bioactivity againt Staphylococcus aureaus. Oliveria (2008) shows the intoxication caused by fruits and leaves of J. gossypifolia L. in the feeding of sheep, but do not indicate the toxic principles responsible for the poisoning. In Brazil, few studies are related to the structural elucidation and discovery of new compounds.

This work shows the evaluation of the composition of leaves extracts and essential oil obtained from $J$. gossypifolia. The extract was investigated for biological activity against Artemia salina, acidity and saponification index, and the chemical composition of the essential oil and fatty acids.

\section{Material and Methods}

\section{Collect of plant}

The vegetable material (leaves and fruits of Jatropha gossypifolia L.) was collected on February 2012, in Naviraí-MS, in region of pastures near to the "Córrego do Touro". (VASCONCELOS et al., 2011). The vegetable material was taken to laboratory to preparation of extraction of essential oils from the leaves, and of fixed oils from the fruits. The fruits were skinned for separation of albúmen and seeds for extraction of fixed oils. The moisture content for fruits was determined according methodology described by Farmacopéia Brasileira (1988). The samples were added in beckers and placed in oven at $100{ }^{\circ} \mathrm{C}$ for $60 \mathrm{~min}$.

\section{Extraction of fixed oils}

The oils were extracted by using a Soxhlet apparatus (INGERSOLL; FUSON; ROSS, 2009). Approximately $70.25 \mathrm{~g}$ of albumen samples and $49.25 \mathrm{~g}$ of seeds were involved in a paper filter and placed in a Soxhlet apparatus and extracted with 250 $\mathrm{mL}$ of hexane for 6 hours, at reflux. After extraction, the solvent was evaporated in rotary evaporator and the oil collected for calculating the yield. The oil were placed in a glass vial with screw cap and protected from light.

\section{Extraction of essential oil}

The extraction of essential oil was performed in apparatus type Clevenger by hydrodistillation (SANTOS et al., 2004). The leaves (875.9 g) were crushed, placed in $5 \mathrm{~L}$ flask and submitted to extraction for 6 hours. After this time, the oil was removed by use of the ethyl acetate $(5 \mathrm{~mL})$. The solvent was evaporated in ambient temperature, and the oil stored in glass vial with screw cap and protected from light. 


\section{Oil degumming}

For the degumming process, the crude oil was heated at $80^{\circ} \mathrm{C}$ and added $1 \%$ (by weight of oil) of $\mathrm{H}_{3} \mathrm{PO}_{4}(85 \%$ commercial) and $3 \%$ distilled water. The mixture was stirred for $30 \mathrm{~min}$ and centrifuged to separation of the gum (VIEIRA et al., 2009). The supernatant from this centrifugation was taken to a separation funnel in which remained at rest for 30 min. After the formation of the upper phases were collected.

\section{Saponification}

To determination of the soaps content $(1.0 \mathrm{~g}$ of oil) was dissolved in $50 \mathrm{~mL}$ of a $\mathrm{KOH}$ solution $(0.5$ mol $\mathrm{L}^{-1}$ ) and heated at $60{ }^{\circ} \mathrm{C}$, in a reflux system, for $30 \mathrm{~min}$. The solution was titrated with $\mathrm{H}_{2} \mathrm{SO}_{4}$ $\left(0.5 \mathrm{~mol} \mathrm{~L}^{-1}\right)$ with phenolphthalein as indicator. The same procedure was performed with $\mathrm{KOH}$ free in medium. The volume of acid was determined for calculus of the saponification index (SI) by equation 1 (ARAÚJO, 2009):

$$
S I=\frac{\left(V_{B}-V_{A}\right) x M_{1} x M M}{m_{\text {sample }}}
$$

Equation 1

where $V_{B}$ is volume $(\mathrm{mL})$ of spent $\mathrm{H}_{2} \mathrm{SO}_{4}$ solution in the titration, $V_{A}$ is volume $(\mathrm{mL})$ of spent $\mathrm{H}_{2} \mathrm{SO}_{4}$ in the titration of the sample, $M$ concentration $\mathrm{KOH}$ solution, $M M$ molar mass of $\mathrm{KOH}$, and $m$ the mass sample.

\section{Acidity Indict}

To determination of the content of acidity indict in the oil extract from the albumen, $1.0 \mathrm{~g}$ of degummed oil was obtained and dissolved in $15 \mathrm{~mL}$ of ethyl ether/ethanol $(2: 1)$. The solution was titrated with $\mathrm{KOH}\left(0.5 \mathrm{~mol} \mathrm{~L}^{-1}\right)$, with phenolphthalein as indicator. The volume of base was determined and the acidity indict was determined by equation 2 (TIRITAN; BEUX, 2006):

$$
\text { Acidity }=\frac{V x M x 56.1}{m_{\text {sample }}} \quad \text { Equation } 2
$$

where $V$ is the volume $(\mathrm{mL})$ of $\mathrm{KOH}$ solution spent in the titration of the sample, $M$ concentration $\mathrm{KOH}$ solution, $f$ is the correction factor of $\mathrm{KOH}$ solution and $m$ is the weight $(g)$ of sample.

\section{Cytotoxic Assay on Artemia salina sp.}

The cytotoxic assay with Artemia salina was performed according the methodology described by MEYER et al., (1982) with modification. Marine saturated solution (38 $\mathrm{g} \mathrm{L}^{-1)}$ was prepared by dissolution of sea salt in distilled water. For 500 $\mathrm{mL}$ the water the $\mathrm{pH}$ was adjusted between 8-9 and $1.5 \mathrm{~g}$ the $A$. salina eggs placed for hatching and subjected to shock light with $100 \mathrm{~W}$ lamp for 48 hours, protected from dust an insects. The oils obtained from the albumen, seed and leaves (10 $\mathrm{mg}$ ) were solubilized in methanol and volume completed to $5 \mathrm{~mL}$ with distillate water. Aliquots of these solutions were taken and transferred to 5 $\mathrm{mL}$ tubes and the volume completed with marine water to a concentration of 500, 250, 100, 50 and $10 \mu \mathrm{g} . \mathrm{L}^{-1}$ to each sample. Under the same condition the lacpachol, a natural organic compound was perpetrated with positive control. For each dilution of the samples and controls, 10 larvae of A. salina was placed with a Pasteur pipette. After 24 hours under controlled lighting and temperature was performed counting of the living and dead larvae. The lethal dose-level of $50 \%\left(\mathrm{LD}_{50}\right)$ was calculated by Probit analysis, using software Biostat $2008 \mathrm{v}$. 5.2.5 with $95 \%$ significance.

\section{Identification of fatty acids}

The trans-esterification was carried out according to ISO method 5509 (ISO, 1978) using $\mathrm{KOH} 2$ mol L ${ }^{-1}$ in methanol. Fatty acid methyl esters were analyzed using gas chromatography (GC) HP 5890 
equipped with flame ionization detector (FID) and fused silica capillary column (60 m x $0.25 \mathrm{~mm}$ and $0.25 \mu \mathrm{m}$ of $100 \%$ polyethyleneglycol). The $\mathrm{N}_{2}$ flow (carrier gas) was $1.2 \mathrm{~mL} \mathrm{~min}^{-1}$, with $30 \mathrm{~mL} \mathrm{~min}^{-1}$. and $300 \mathrm{~mL} \mathrm{~min}^{-1}$., for $\mathrm{H}_{2}$ and synthetic air, for the flame detector. The volume injected was $2.0 \mu \mathrm{L}$, using a sample splitter 1:80, with temperatures of the injector and detector at $250{ }^{\circ} \mathrm{C}$, respectively. The column temperature was $160{ }^{\circ} \mathrm{C} / 5 \mathrm{~min} \rightarrow 5^{\circ} \mathrm{C} / \mathrm{min} \rightarrow 200$ ${ }^{\circ} \mathrm{C} / 10 \mathrm{~min} \rightarrow 3{ }^{\circ} \mathrm{C} / \mathrm{min} \rightarrow 235^{\circ} \mathrm{C} / 60 \mathrm{~min}$. The peak areas were determined by the software N2000 Chromatostation. The identification of the fatty acid methyl esters (FAME) was performed by comparing the retention time of the sample constituents with a mixture of 37 standards of fatty acid methyl ester from Sigma-Aldrich. The percentage the each acid was performed by total area normalized through the equation $\% N=\left(A c_{t r} / \Sigma A c_{\text {total }}\right) \times 100 \%$, where $\% N$ is a percentage obtained, $A c_{t r}$ is fatty acid obtained and $A c_{\text {total }}$ is total area this chromatographic peak.

\section{Identification of compounds essential oil}

The essential oil obtained from the leaves was analyzed by gas chromatography coupled to mass spectrometry (GC-MS Thermo Finigan). The analyses were performed in COMCAP in State University of Maringá (UEM). The condition of temperature of injector and detector were $250^{\circ} \mathrm{C}$, respectively. The column temperature was $50^{\circ} \mathrm{C}$ with elevation of $4{ }^{\circ} \mathrm{C} / \mathrm{min}$ at $250^{\circ} \mathrm{C} / 5 \mathrm{~min}$, transference line of $240^{\circ} \mathrm{C}$. The flow of carrier gas was helio in $1.2 \mathrm{~mL} \cdot \mathrm{min}^{-1}$ and ionization by electron impact (EI) of $70 \mathrm{eV}$. One micro litters of oil was injected in split mode with ratio 1:100. The confirmation and identification of the chromatographic peaks was performed by comparing the mass spectrum of the library NIST 32, Kovats indices (KI) calculation and comparing with Adams (2007) library.

\section{Results}

In Table 1 are showed the results for the fruits of $J$. ribifolia. The fruits obtained were separated in seeds $(50.03 \mathrm{~g})$ and albumens $(72.15 \mathrm{~g})$ for determination of moisture content according the methodology described by Farmacopéia Brasileira (1988). This method is based on the loss of water by drying in an oven with aim to determine the amount of volatile substances of any type disposed under the specified conditions. Table 1 show that the moisture content is low for seed and albumen.

Table 1 - Moisture content for seeds and albumen of the $J$. gossypifolia $\mathrm{L}$. fruits $(\mathrm{n}=3)$.

\begin{tabular}{c|c|c}
\hline Samples & Weight (g) & Moisture (\%)* \\
\hline Seeds & 50.03 & $2.65 \pm 0.54$ \\
\hline Albumen & 72.15 & $1.57 \pm 0.54$ \\
\hline
\end{tabular}

Fonte: Dados do autor.

The content of oil extracted showed a yield of $26.6 \%$ and $38.4 \%$ for seeds and albumen, respectively. The oils had a faint smell of nuts with pale yellow coloration. The essential oil obtained from the leaves showed a green color and odorless. The hydrodistillation yield was the $0.0365 \%$. The degumming process of oil was important to remove the proteins, phospholipids, ash and impurities in analysis of the acidity and saponification.

\section{Saponification and acidy indict}

The saponification is a reaction between oils and alkali, in press and heating moderated. The reaction affords glycerol and free fatty acid in the soap form (OLIVEIRA et al., 2006). The value found for the SI of albumen oil was $165.4 \mathrm{mg} \mathrm{KOH} \mathrm{g}^{-1}$ of sample. According to ANVISA (1999), the IS for vegetable oils should be between 189 and $195 \mathrm{mg}$ $\mathrm{KOH} \mathrm{g}^{-1}$. The acidy indicts showing the value of 10 
$\%\left(5.61 \mathrm{mg} \mathrm{g}^{-1}\right)$. This value is high to the acidity indict, which cannot reach values above $1 \%$ to the vegetable oils. (ALVES et al., 2009; DORSA et al., 2004). These free fatty acids are undesirable element that can cause undesirable odor and flavor (MORETTO; FETT, 1998).

\section{Cytotocity assay on Artemia salina}

The Artemia salina L brine shrimp assay is a simple and efficient method for the evaluation of acute toxicity of extracts and oils obtained from plants. According David et al. (2001) plant extracts presenting DL50 $>1000 \mu \mathrm{g} \mathrm{mL}^{-1}$, in the cytotoxic assay, are considered inactive. To DL50 < $100 \mu \mathrm{g}$ $\mathrm{mL}^{-1}$ is highly active and may present cytotoxic activity. Extracts with DL50 $\geq 100$ and $\leq 1000 \mu \mathrm{g}$ $\mathrm{mL}^{-1}$ have moderate activity. Table 2 shows the values of DL50 obtained for oils extracted. Leaves and albumen essential oils showed cytotoxic activity, with DL50 lower than $100 \mu \mathrm{g} \mathrm{mL} \mathrm{m}^{-1}$, while the seed oil presents moderated activity, with DL50 $\geq 100$ and $\leq 1000 \mu \mathrm{g} \mathrm{mL}^{-1}$. This result is satisfactory since are reported in literature that jatropha has been used in fighting diseases such as cancer, hemorrhoids, burn, venereal disease etc. thus proving the cytotoxic activity presented (GBEASSOR et al., 1989).

Table 3 - Percentagem of fatty acids obtained for the extract oil the seeds and albúmen the J. gossypifolia L.

\begin{tabular}{|c|c|c|}
\hline Fatty acids & *Seeds (\%) & Albúmen (\%) \\
\hline C13:0 (tridecanoic acid) & 0.08 & - \\
\hline C14:0 ( mirystic acid) & 0.19 & 0.05 \\
\hline C15:0 ( pentadecanoic acid) & 0.03 & 0.04 \\
\hline C16:0 ( palmític acid) & 3.98 & 12.72 \\
\hline $\mathrm{C} 16: 1$ (palmitoleic acid) & 0.02 & 0.33 \\
\hline C17:0 ( heptadecanoic acid) & 35.81 & 0.24 \\
\hline C17:1 ( cis-10-heptadecanóico acid) & - & 0.10 \\
\hline $\mathrm{C} 18: 0$ ( estearic acid) & 2.85 & 7.83 \\
\hline 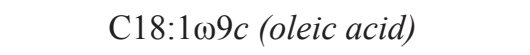 & 7.40 & 19.96 \\
\hline 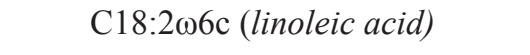 & 24.09 & 55.18 \\
\hline C18:3w3 ( linolenic acid) & 0.48 & 1.48 \\
\hline C20:0 ( arachidic acid) & 0.10 & - \\
\hline SFA & 43.04 & 20.88 \\
\hline MUFA & 7.42 & 20.39 \\
\hline PUFA & 24.57 & 56.66 \\
\hline PUFA/SFA & 0.57 & 2.71 \\
\hline
\end{tabular}

* Percentage of acids determined in chromatograma 75,08 \%. SFA=saturated fatty acid; MUFA=monounsaturated fatty acid; PUFA=polyunsaturated fatty acid.

Fonte: Dados do autor 
Table 4 - Essential oil composition of leaves J. gossypifolia L. by GC-MS.

\begin{tabular}{ccccccc}
\hline & RT & Compounds & Formule & $*$ KI & KI & (\%) \\
\hline 1 & 17.68 & $\alpha$-terpineol & $\mathrm{C}_{10} \mathrm{H}_{18} \mathrm{O}$ & 1188 & 1186 & 0.22 \\
2 & 19.89 & geraniol & $\mathrm{C}_{10} \mathrm{H}_{18} \mathrm{O}$ & 1253 & 1249 & 0.25 \\
3 & 23.93 & $\alpha$ - copaene & $\mathrm{C}_{15} \mathrm{H}_{24}$ & 1374 & 1374 & 4.52 \\
4 & 25.30 & $\beta$-caryophyllene & $\mathrm{C}_{15} \mathrm{H}_{24}$ & 1417 & 1417 & 1.49 \\
5 & 28.20 & $p$-cresol, 2,6-di-tert-butyl- & $\mathrm{C}_{15} \mathrm{H}_{24} \mathrm{O}$ & 1511 & 1514 & 10.18 \\
6 & 28.50 & cadinene & $\mathrm{C}_{15} \mathrm{H}_{24}$ & 1538 & 1537 & 7.28 \\
7 & 29.66 & nerolidol<(E)> & $\mathrm{C}_{15} \mathrm{H}_{26} \mathrm{O}$ & 1561 & 1561 & 0.73 \\
$\mathbf{A}$ & 30.89 & humulane-1,6-dien-3-ol & $\mathrm{C}_{15} \mathrm{H}_{26} \mathrm{O}$ & 1621 & $\mathrm{ND}$ & 21.28 \\
8 & 31.93 & Muurolol $<$ epi- $\alpha->$ & $\mathrm{C}_{15} \mathrm{H}_{26} \mathrm{O}$ & 1640 & 1640 & 3.62 \\
9 & 32.27 & cadinol< $\alpha->$ & $\mathrm{C}_{15} \mathrm{H}_{26} \mathrm{O}$ & 1652 & 1652 & 2.36 \\
10 & 40.94 & hexadecanoic acid, ethyl ester & $\mathrm{C}_{18} \mathrm{H}_{36} \mathrm{O}_{2}$ & 1991 & 1993 & 0.43 \\
11 & 43.67 & phytol & $\mathrm{C}_{20} \mathrm{H}_{40} \mathrm{O}$ & 2033 & 2133 & 15.58 \\
12 & 44.88 & linolenic acid, ethyl ester & $\mathrm{C}_{20} \mathrm{H}_{34} \mathrm{O}_{2}$ & 2188 & 2194 & 1.55 \\
& & & & $\Sigma T 0 t a l$ & 69.49 \\
\hline
\end{tabular}

*KI - calculated Kovats indict; KI - literature indict; RT - Retention Time (min); ND - not detected.

Fonte: Dados do autor.

Figure 1 - The total íns chromatograms (TIC) of essential oil compounds of J. gossypifolia by GC-MS.

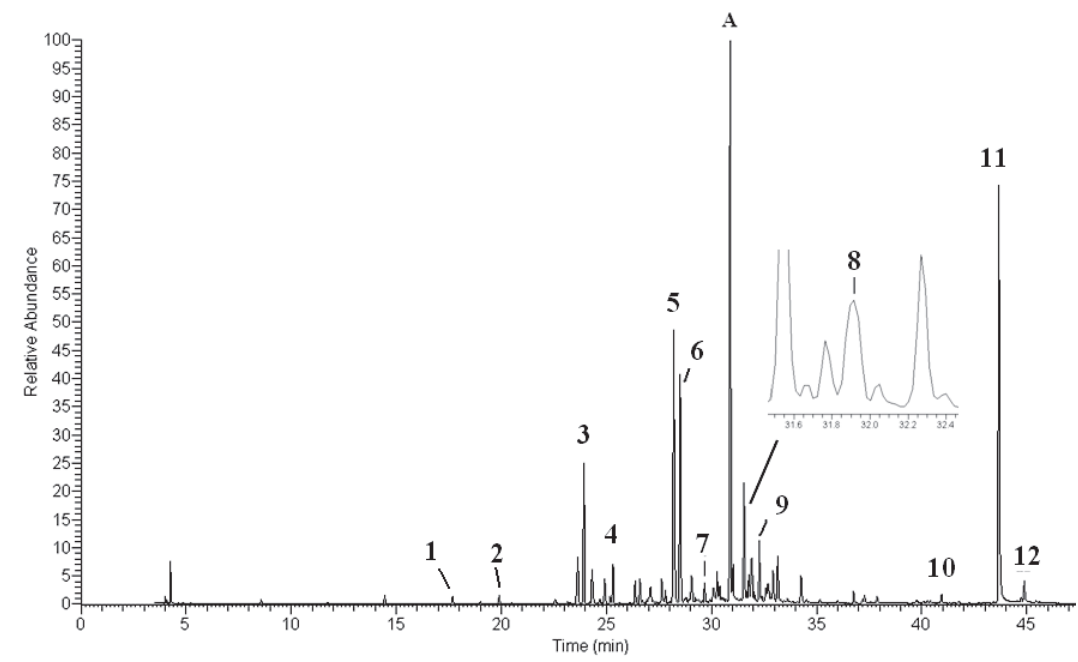

Fonte: Dados do autor

Table 2 - Cytotoxic assay on $A$. salina for the oils extract from Jatropha gossypifolia L.

\begin{tabular}{cc}
\hline Oils Samples & $\mathbf{D L}_{\mathbf{5 0}} \boldsymbol{\mu} \mathbf{g} \mathbf{~ m L}^{-1 *}$ \\
\hline Leaves & $78.66 \pm 0.25$ \\
Albúmen & $74.25 \pm 0.21$ \\
Seeds & $397.76 \pm 0.45$ \\
\hline
\end{tabular}

*Avarege \pm standard deviation for three measures.

Fonte: Dados do autor.

\section{Chromatographic analysis}

The fatty acids chromatographic profile obtained for albumen and seeds are equivalent between themselves. However, the chromatographic profile for the oil extracted from the seeds showed a high amount of the chromatographic peak not identified by comparison to the standard of methyl ester analyzed by GC-FID. In Table 3 are showed the 
fatty acid composition. For the oil seeds, the fatty acids present in major percentage are palmitic (C16:0), stearic (C18:0), oleic (C18:1n9c) and linoleic $(\mathrm{C} 18: 2 \mathrm{n} 6 \mathrm{c})$. In this case, no difference was observed in the composition of the analyzed oil of the albumen. For the seeds oils, the heptadecanoic acid was found in major percentage among all acids, with $35.81 \%$. The composition was lower than the other acids (C16:0; C18:0; C18:1n9c and C18:2n6c) with varying from 2.85 to $24.09 \%$ percentages. The fatty acids determined in the $J$. gossypifolia extracts are recognized as those who perform important function in our body. Palmitic acid is important for infant nutrition (RADMANN; COSTA, 2008), and stearic acid acts as important precursor of the oleic acid (YONG, 2002). Oleic acid is considered essential to our metabolism, acting in hormone synthesis and as a w-9 fatty acids precursor (YOUNG, 2002; VIANNI; BRAZFILHO, 1996). The PUFA/SFA ratio was adequate for consumption of oils analyzed, being above 0.45 as determined by the English health department. However, the albumen oil presents high toxicity against the $A$. salina microcustacean $\left(\mathrm{LD}_{50} 74,25 \pm\right.$ $\left.0,21 \mu \mathrm{g} \mathrm{mL}^{-1}\right)$.

Essential oils extract of the leaves were analyzed by gas chromatography coupled to mass spectrometry. The total ions chromatogram (TIC) is showed in Figure 1. Twelve compounds were identified by GC-MS analysis (Table 3). The identification was made by NIST and Adams (2007) library. The compounds determinated in the TIC correspond to the $69.49 \%$ of identified compounds. However, the major peak (A) of TIC was not identified by Kovatz index and Adams (2007) library. The oil compositions present too a natural antioxidant in large percentage, the butylated hydroxytolune $(10.18 \%)$. This indicates that these extracts may exhibit antioxidant properties.

\section{Conclusion}

The potential of fruits and leaves the $\mathrm{J}$. gossypifolia as raw material for fatty acids and essential oil production has been evaluated. The albumen show high content of fatty material that can be utilized to as source for biofuel production. Although the acidity index and saponification are unsuitable for consumption, the PUFA/SFA ratio was higher than that indicated by the English health department (HMSO, 1994). The ratio was the 2.71 and 0.57 for albumen and seeds, respectively. Cytotoxic activity was observed for the oil leaves and albumen extract in the A. salina assay. A total 13 compounds were identified to the essential oil of the leaves when compared to the IK literature.

\section{Referências}

ADAMS, R. P. Identification of essential oil components by gas chromatography / mass spectrometry. $4^{\mathrm{a}}$ Edition, 2007.

ALVES, R. F.; GUIMARÃES, S. M.; ABREU T. C.; SILVA, R. D. Índices de acidez livre e de peróxido. São José dos Campos, SP, 2009. Relatório para a Disciplina de Bioquímica, Curso Técnico de Química Industrial, Centro de Educação Profissional Hélio Augusto de Sousa.

AGÊNCIANACIONAL DE VIGILÂNCIASANITÁRIA - ANVISA. Resolução - RDC - $n^{\circ} 482$, de 23 de setembro de 1999. Regulamento Técnico para fixação de identidade e qualidade de óleos e gorduras vegetais. D.O.U. - Diário Oficial da União, 1999.

ARAÚJO, J. M. A. Química de alimentos: teoria e pratica. 4. ed. Viçosa: UFV, 2009.

BISWANATH, D.; KASHINATHAM, A.; VENKATAIAH, B.; SRINIVAS, K. V. N. S.; MAHENDER, G.; REDDY, M.R. Cleomiscosin A, a coumarino-lignoid from Jatropha gossypifolia. Biochemical Systematics and Ecology, Hyderabad India, v. 31, n. 10, p. 1189-1191, 2003.

DAVID, J. P.; DA SILVA, E. F.; DE MOURA, D. L.; GUEDES, M. L. S.; ASSUNÇÃO, R. J.; DAVID, J. M. Ligninas e triterpenos do extrato citotóxico de Eriope blancheti. Química Nova, Salvador, v. 24, n.6, p. 730, 2001. 
DORSA, R. Tecnologia de óleos vegetais. Campinas: Ideal, 2004.

FARMACOPÉIA brasileira. 4. ed. São Paulo: Atheneu, 1988.

GBEASSOR, M.; KOSSOU, Y.; AMEGBO, K.; DE SOUZA, C.; KOUMAGLO, K.; DENKE, A. Antimalarial effects of eight African Medicinal Plants. $J$. Ethnopharmacology, Togo - West Africa, v. 25, Issue 1, p. 115-118, 1989.

INGERSOLL, A.W.; FUSON, R.C.; ROSS, E. Organic Synthesis, Collective Vol. 2, p. 503-506. Assymetric Synthesis, Ed. Morrison, J.D.; Academic Press, vol. 1 a 5. Fev. 2009.

ISO - INTERNATIONAL ORGANIZATION FOR STANDARDIZATION. Animal and vegetables fats and oils: preparation of methyl esters of fatty acids. Geneve: ISO. Method ISO 5509. p. 1-6. 1978.

MEYER, B. N.; FERRIGNI, N. R.; PUTNAM, J. E.; JACOBSEN, L. B.; NICHOLS, D. E.; MCLAUGHLIN, J. L. Brine Shrimp: A Convenient General Bioassay for Active Plant Constituents Planta Medica, v. 45(5), p.3134, 1982.

MORETTO, E.; FETT, R. Tecnologia de óleos e gorduras vegetais na indústria de alimentos. São Paulo: Varela, 1998.

OLIVEIRA, L. I.; JABOUR, F. F.; NOGUEIRA, V. A.; YAMASAKI, E. M. Intoxicação experimental com folhas de Jatropha gossypifolia (Euphorbiaceae) em ovinos. Pesquisa Veterinária Brasileira, Rio de Janeiro, v. 28 , n. 6 , p. 275-278, 2008.

TIRITAN, M. G.; BEUX, S. Controle da qualidade do óleo de soja degomad. Synergismus scyentifica. Pato Branco, UTFPR, $01(1,2,3,4)$ : 1-778, 2006. Artigo de revisão.

RADMANN, E. M.; COSTA, J. A. Conteúdo lipídico e composição de ácidos graxos de microalgas expostas aos gases $\mathrm{CO}_{2}, \mathrm{SO}_{2}$ e NO. Química Nova, Rio Grande - RS, v. 31, n. 7, p. 1609-1612, 2008.
RAVINDRANATH, N.; VENKATAIAH, B.; RAMESH, C.; JAYAPRAKASH, P.; DAS, B. Jatrophenone, a novel macrocyclic bioactive diterpene from Jatropha gossypifolia. Chemical \& Pharmaceutical Bulletin, Hyderabad, India, v. 51, n. 7, p. 870-871, 2003.

SANTOS, A. S.; ALVES, S. M.; FIGUEIRÊDO, F. J. C.; ROCHA NETO, O. G. Descrição de Sistema e de Métodos de Extração de Óleos Essenciais e Determinação de Umidade de Biomassa em Laboratório. Embrapa: Comunicado Técnico, Belém, PA, n. 99, nov. 2004.

SERVIN, S. C. N.; TORRES, O. J. M.; MATIAS, J. E. F.; AGUlHAM, M. Â.; CARVALHO, F. A.; LEMOS, R.; SOARES, E. W. S.; SOLTOSKI, P. R.; FREITAS, A. C. T. Ação do extrato de Jatropha gossypifolia L. (pião roxo) na cicatrização de anastomese colônica: estudo experimental em ratos. Acta Cirúrgica Brasileira, São Paulo,v. 21, n. 3, p. 89-96, 2006.

VASCONCELOS, G. C. L.; MEDEIROS, K. A. A. L.; MEDEIROS, N. I.; DE LUCENA, A. M. A.; ARRIEL, N. H. C. Caracterização morfológica comparativa de Jatropha curcas L., Jatropha mollissima (Pohl.) Baill. e Jatropha gossypiifolia L. In: CONGRESSO BRASILEIRO DE PESQUISAS DE PINHÃO-MANSO, 2., 2011, Brasília.

VIANNI, R.; BRAZ-FILHO, R. Ácidos graxos naturais: importância e ocorrência em alimentos. Química Nova, Campos- RJ, v. 19, n. 4, p. 400-407, 1996.

VIEIRA, A. C.; BARRETO, M. L. G.; VASCONCELOS, V. M.; SILVA, G. F. Degomagem de óleo de girassol para produção de biodiesel. In: CONGRESSO BRASILEIRO DE ENGENHARIA QUÍMICA EM INICIAÇÃO CIENTÍFICA, 8., 2009, Uberlândia.

YOUNG, A. J. Chemical education today. Journal of Chemical Education, http://www.jce.divched.org/,v. 79, n. 1, p.24-24, 2002. 